\title{
補強盛土一体橋梁における橋梁部の伸縮挙動と 背面盛土の沈下状況に関する一考察
}

\author{
佐々木徹也 1 ・西岡英俊 1 -小島謙一 2 ・高野裕輔 3 ・陶山雄介 4 ・青木一二三 5
}

\begin{abstract}
背面盛土を補強土構造とし，橋桁・橋台と一体化させた補強盛土一体橋梁（GRS一体橋梁）が北海道新幹線 で実構造物として初めて適用され，施工時および長期動態計測が実施されている．GRS一体橋梁の特徴により， コンクリートの伸縮作用による強制変位により背面盛土内に敷設された補強材（ジオテキスタイル）に引張変 位が多数繰り返し生じる．また，アプローチブロックの背面方向への変位が生じることで補強材に対して引張 変位が作用する可能性が䀣念される，本論文では，長期動態計測より得られたデータを整理し，補強材の引張 変位に影響を与える橋梁部の伸縮挙動と背面盛土（セメント改良アプローチブロック）の沈下状況について, 実構造物の挙動を踏まえて考察した。
\end{abstract}

キーワード : GRS一体橋梁, ジオテキスタイル，引張変位

\section{1.はじめに}

背面盛土を補強土構造とし，橋桁・橋台と一体化さ せた補強盛土一体橋梁 ${ }^{1}$ (以下, GRS 一体橋梁) が北海 道新幹線で実構造物として初めて適用され，施工時およ び長期動態計測が実施されている（図-1）。現場の状況 や橋梁構造，施工時の挙動については文献 2)に，長期 動態計測については文献 3)〜4)に詳しい.

GRS 一体橋梁では，背面盛土の沈下を防止するため に, 粒度調整砕石（以下, 粒調砕石）あるいはセメント 改良磁土による台形形状のアプローチブロックが構築さ れる．また，壁体とアプローチブロックがジオテキスタ イル（以下，補強材）によって一体化されており，常時 あるいは地震時における作用に対し補強材の引張力が抵 抗力として有効に作用することとなる.

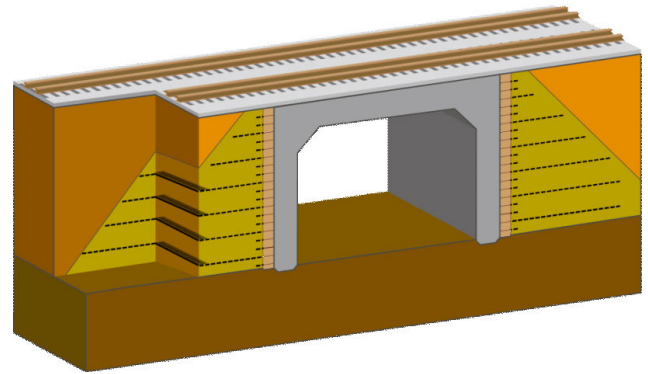

図-1ＧRS一体橋梁

GRS 一体橋梁と近い形式として, 背面盛土にアプロ 一チブロックを配置し，壁体とアプローチブロックがジ
オテキスタイルで一体化されている補強土橋台があるが, 両者の大きな違いとして，コンクリートの伸縮により多 数の繰り返し作用を受けるという点にある.この伸縮作 用は主に，上床版の収縮作用のほか，温度変化による伸 縮作用であるが，橋梁部之背面盛土が一体化されている ことにより補強材に繰返し引張変位が作用することとな る.さらに，背面盛土のアプローチブロックにセメント 改良砅土が用いられている場合，アプローチブロック自 体は剛性や自立性が高いものとなるが，支持地盤が沈下 等を引き起こす場合には，アプローチブロックの背面方 向への変位が生じることで補強材に対して引張変位が作 用する可能性がある.

本論文では，現地計測より得られたデータより，補 強材の引張変位に影響を与える橋梁部の伸縮挙動と背面 盛土（セメント改良アプローチブロック）の沈下状況に ついて実構造物の挙動を踏まえて考察する.

\section{2. 橋梁部の伸縮挙動の確認}

北海道新幹線におけるGRS一体橋梁は，橋梁部が直接 基礎のRCラーメン構造（橋長 $12 \mathrm{~m}$ ），背面盛土がセメン 卜改良アプローチブロックであり，壁体とアプローチブ ロックがジオテキスタイルで一体化されている. なお, 背面盛土の構築時の仮抑え材には土のうを用いている. 北海道新幹線におけるGRS一体橋梁での計測項目のう

\footnotetext{
1地盤工学会員，公益財団法人鉄道総合技術研究所 構造物技術研究部（干185-8540 東京都国分寺市光町2-8-38） 2正会員，公益財団法人鉄道総合技術研究所 鉄道地震工学研究センター（†185-8540 東京都国分寺市光町2-8-38）

3地盤工学会員，独立行政法人 鉄道建設・運輸施設整備支援機構＼cjkstart設計技術部（一231-8315 横浜市中区本町6-50-1） 地盤工学会員，独立行政法人 鉄道建設・運輸施設整備支援機構 九州新幹線建設局（广812-8622 福岡県福岡市博多区祗園町2-1） 5正会員，株式会社レールウェイエンジニアリング＼cjkstart技術部（†231-8315 横浜市中区本町6-50-1）
} 


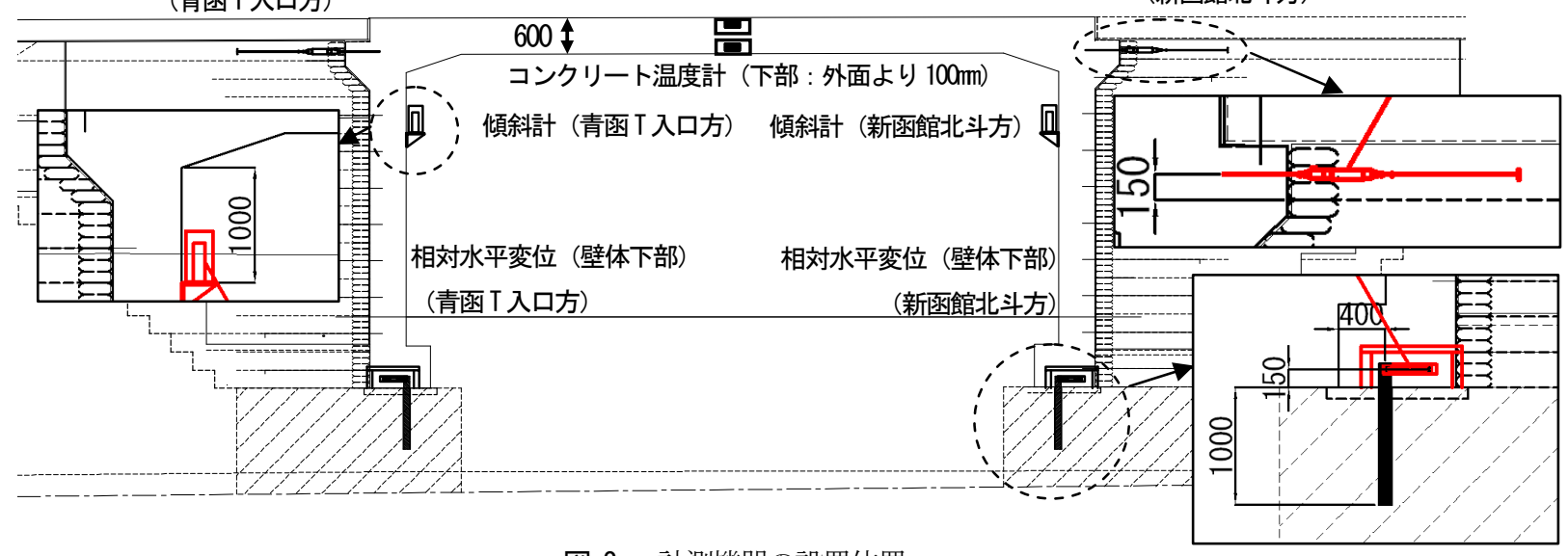

図-2＼cjkstart計測機器の設置位置

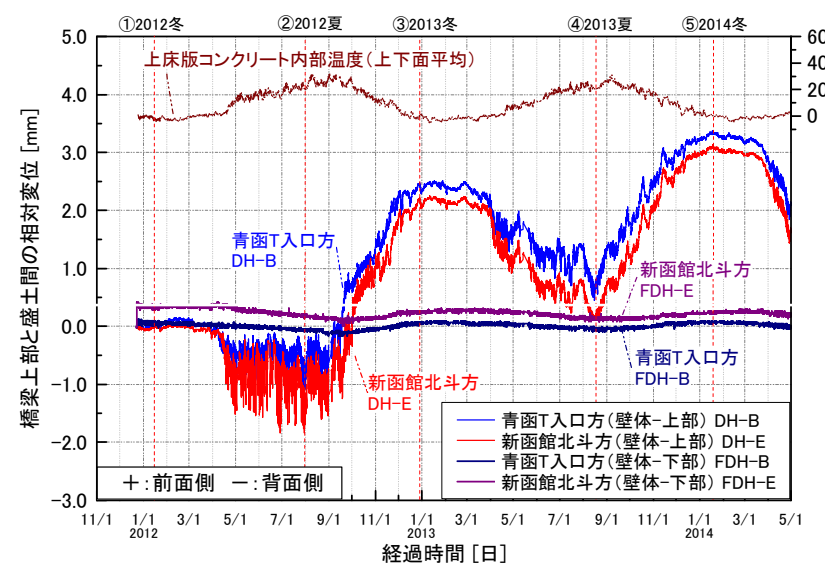

図-3 相対水平変位の経時変化（壁体上部・下部）

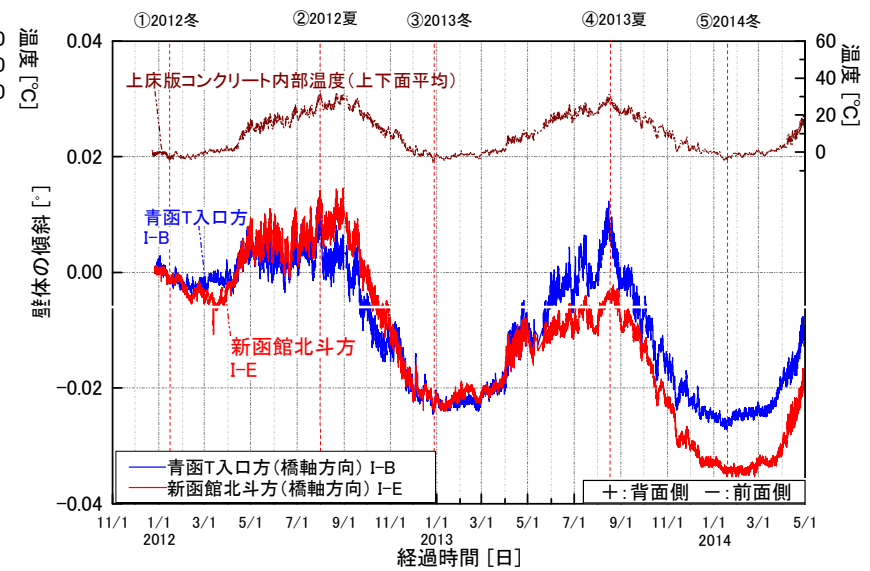

図-4 壁体傾斜計の経時変化（壁体上部）

表-1 上床版コンクリート内部温度（極值）と相対水平変位および壁体傾斜角

\begin{tabular}{|c|c|c|c|c|c|c|c|c|c|c|}
\hline \multirow[b]{2}{*}{ No. } & \multirow[b]{2}{*}{ 日時 } & \multicolumn{3}{|c|}{ 温度 } & \multicolumn{4}{|c|}{ 相対水平変位 } & \multicolumn{2}{|c|}{ 壁体傾斜角(背面：十、前面：一) } \\
\hline & & \multicolumn{2}{|c|}{$\begin{array}{c}\text { 上床版コンクリート } \\
\text { 内温度 } \\
\text { (上下部平均) } \\
\text { Tcon }\left({ }^{\circ} \mathrm{C}\right) \\
\end{array}$} & $\begin{array}{l}\text { 外気温 } \\
\text { Tair }\left({ }^{\circ} \mathrm{C}\right)\end{array}$ & $\begin{array}{l}\text { 青函丁入口方 } \\
\text { 壁体-上部 } \\
\text { 相対水平変位 } \\
(\mathrm{mm})\end{array}$ & $\begin{array}{l}\text { 青函T入口方 } \\
\text { 壁体-下部 } \\
\text { 相対水平変位 } \\
(\mathrm{mm})\end{array}$ & $\begin{array}{l}\text { 新函館北斗方 } \\
\text { 壁体一上部 } \\
\text { 相対水平変位 } \\
(\mathrm{mm})\end{array}$ & $\begin{array}{l}\text { 新函館北斗方 } \\
\text { 壁体一下部 } \\
\text { 相対水平変位 } \\
(\mathrm{mm})\end{array}$ & $\begin{array}{c}\text { 青函入入口方 } \\
\text { 壁体傾斜計 } \\
\text { 傾斜角 } \\
(\mathrm{deg})\end{array}$ & $\begin{array}{l}\text { 新函館北斗方 } \\
\text { 壁体傾斜計 } \\
\text { 傾斜角 } \\
(\mathrm{deg})\end{array}$ \\
\hline (1) & 2012. 1.14 & 最低 & -4.2 & -4.8 & 0.045 & -0.047 & -0.029 & -0.103 & -0.001308 & -0.001115 \\
\hline (2) & 2012. 7.31 & 最高 & 32.4 & 43.9 & -0.930 & -0.097 & -1.646 & -0.201 & 0.010503 & 0.013465 \\
\hline (3) & 2012. 12.27 & 最低 & -5.8 & -11.9 & 2.434 & -0.026 & 2.173 & -0.175 & -0.023358 & -0.023325 \\
\hline (4) & 2013. 8.15 & 最高 & 31.5 & 42.3 & 0.477 & -0.074 & 0.115 & -0.227 & 0.010973 & -0.003555 \\
\hline (5) & 2014. 1.15 & 最低 & -4.6 & -4.9 & 3.346 & 0.0213 & 3.106 & -0.150 & -0.026565 & -0.034079 \\
\hline
\end{tabular}

ち，補強材の引張変位量を直接計測する相対水平変位計 (セメント改良アプローチブロック〜壁体間の変位を計 測）と，壁体の挙動を間接的に表す壁体上端の傾斜計の データを用いて橋梁の伸縮挙動について考察する．考察 の対象とする相対水平変位計と傾斜計のほか，上床版コ ンクリート内部温度計の設置位置を図-2に示す. 図-3,

図-4に各変位・傾斜角と上床版コンクリート内部温度の 時刻歴データを示す。また，施工完了後からの各夏・冬 毎の上床版コンクリート内部温度の極值と，同時刻にお ける橋梁近傍に設置している外気温計の計測值および相 対水平変位・壁体傾斜角を表-1に示す．図-3，図-4より， 前面側に変位が累積しつつ, 温度に応じて伸縮している のが確認され，これはコンクリートの乾燥収縮の影響と，
温度変化による伸縮の影響によるものと考えられる．施 工後2年を経過しても収縮側に変位が累積する傾向が進 展しており，乾燥収縮ひずみは収束には至っていないこ とがわかる．また，壁体下部の変位量は，上部の変位量 と比較して小さなものとなっており，フーチング部はほ とんど変位していないものと判断できる.

\section{3. 相対水平変位と壁体傾斜角の関係}

今回の計測で設置している相対水平変位計はセメン 卜改良アプローチブロックと壁体との相対変位を計測し ているものであるため, 挙動の評価のためには，上床版 


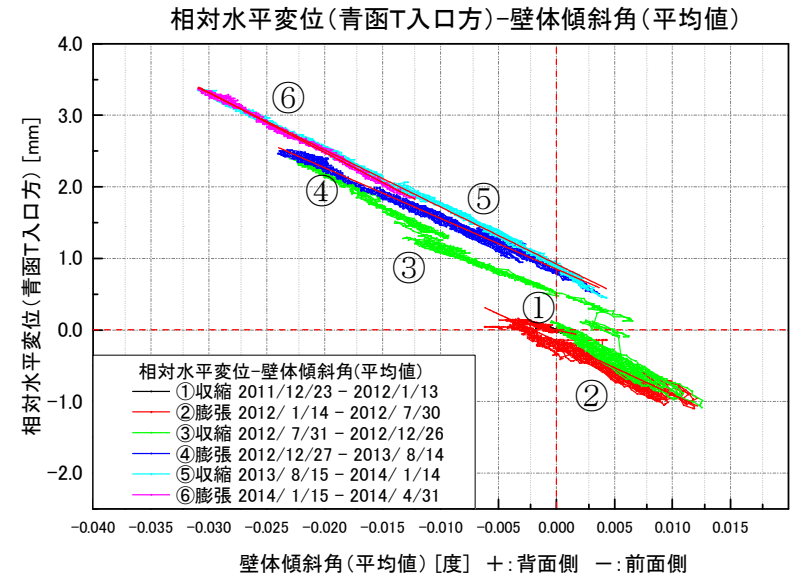

図-5 相対水平変位と壁体傾斜角の関係（青函T入口方）

の伸縮と, アプローチブロック自体の変位について分離 をさせる必要がある．相対水平変位と壁体傾斜角の関係 から，アプローチブロックの変位について考察する．相 対水平変位と壁体傾斜角の関係図を図-5，図-6に示寸. なお，壁体傾斜角については両側で計測された值の平均 值を用いている.

図-5，図-6 の関係より，相対水平変位と壁体傾斜角 に相関が見られることが分かる．橋梁部がラーメン構造 となっており，上床版の伸縮と壁体の傾斜が連動してい るためであると考えられる．また，時間の経過とともに， 同じ傾斜角においても変位に差が見られ，設置初期時か ら比べて相対水平変位計の值が青函トンネル入口方にお いては約 $1 \mathrm{~mm}$ 程度, 新函館北斗方においては約 $0.5 \mathrm{~mm}$ 程度大きな值を示していることが確認できる. 相対水平 変位と壁体傾斜角の相関関係は保たれていること，また， 図-3 より壁体下端においては変位が生じていないこと が確認されていることから, 相対水平変位計のセメント 改良アプローチブロック側の不動点が背面方向へ変位し ているものと考えられる.

\section{4. アプローチブロックの背面方向への変位}

セメント改良アプローチブロック側の変位の発生理

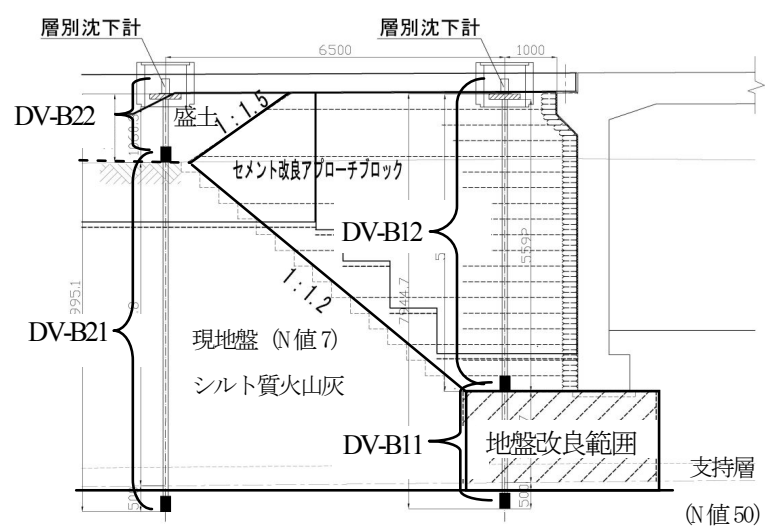

図-7 層別沈下計設置位置（青函T人口方）

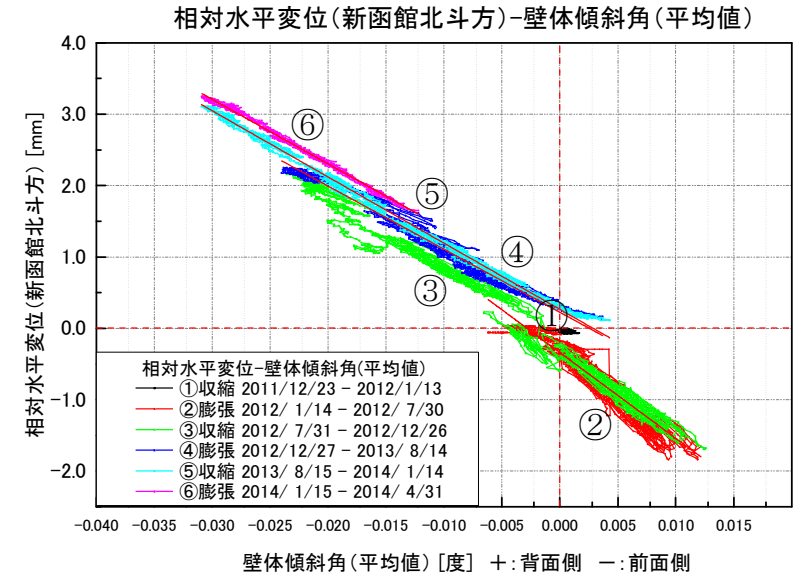

図-6 相対水平変位と壁体傾斜角の関係（新函館北斗方）

由について考察するため，図-7 に示す背面盛土部に設 置している層別沈下計の計測結果について考察する. 当 該箇所では，N值 7程度の現地盤（シル卜質火山灰）を 図-7 に示す範囲を地盤改良した上で逆台形型（盛土下 側が短辺）のセメント改良アプローチブロック及び橋梁 基礎を設置している．また，施工上の都合により，背面 盛土のうちセメント改良アプローチブロックよりも後方 の部分が, GRS一体橋梁の打設後に盛土され, その後 に路盤コンクリートが施工されている.

その影響を把握するため，青函トンネル入口方にお いて計測されている各区間の沈下量計測結果を図-8に示 す. セメント改良アプローチブロック端部（壁体から遠 い方）において，支持層からセメント改良アプローチブ ロック底面間（DV-B21）が路盤コンクリート打設によ り約 $3 \mathrm{~mm}$ 圧縮変位しているのが確認されている. セメン 卜改良アプローチブロック底面から盛土天端間（DVB22）では圧縮変位が確認できないことから，N值7程度 の現地盤の圧密沈下が要因で生じていることが考えられ る. なお，層別沈下計はあと施工の背面盛土が完了した 後に設置されているため, 設置以前のこの区間の沈下量 は不明であるが，壁背面に近い層別沈下計の傾向から考 えると，あと施工の盛土荷重による沈下も考えられ，施 工時からの総沈下量は3mmを上回る值であったものと想 定される.

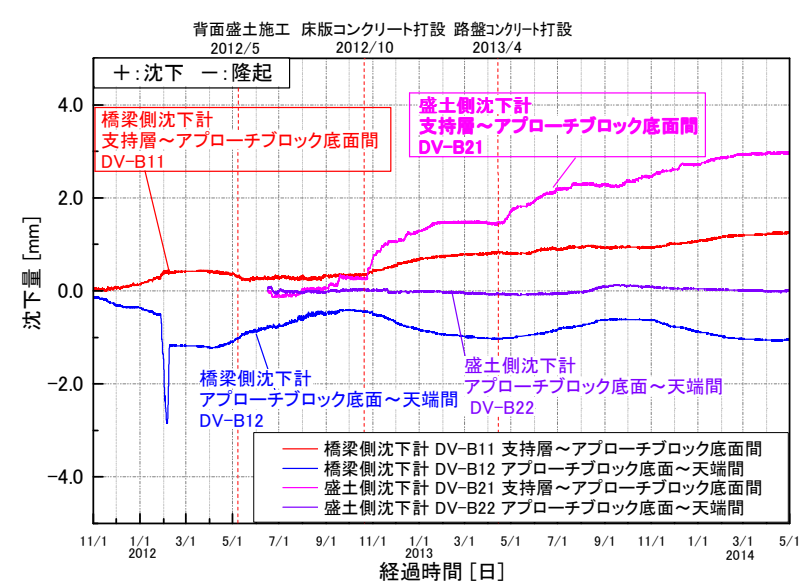

図-8 背面盛土沈下の経時変化（施工完了時を初期值） 
また，壁体背面側の沈下計においても，支持層から セメント改良アプローチブロック下端間（DV-B11）が 約 $1 \mathrm{~mm}$ 圧縮変位しているのが確認されている. アプロー チブロックが逆台形型の形状であり，壁体より離れた位 置ほど現地盤の圧密沈下が生じる結果, 図-9に示すよう にアプローチブロックが剛体的に背面側へ回転変形し, 相対水平変位計の固定端に変位を生じたものと想定され る. なお，セメント改良アプローチブロック内（DVB12）は，本来ほとんど変位は生じないと想定されるが, 地表面の凍上に起因すると考えられる隆起（2012年2月 頃）のほか，年変動傾向を示しており，温度変化に伴う 計測誤差の影響が表れているものと考えられる.

以上より, 背面のアプローチブロックの支持地盤の 圧密沈下が懸念される場合には, 補強材の常時の設計に おいて，これによる補強材の引張変位の影響を設計作用 として考慮する必要があると考えられる. 特にアプロー チブロックが下側を短辺とする台形形状となる場合につ いては，この影響について注意が必要と考えられる.

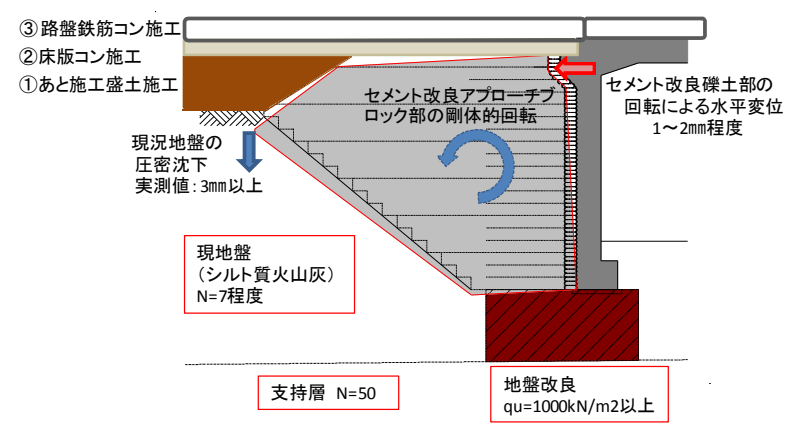

図-9＼cjkstart背面盛士沈下の状況概念図

\section{5. まとめ}

今回は，実施工された GRS一体橋梁における長期動 態計測より得られたデータを整理した結果より, 補強材 の引張変位に影響を与える橋梁部の伸縮挙動之背面盛土 の沈下状況を確認した. 得られた知見を以下に示す.
(1)施工完了後からの経時変動より, コンクリートの乾燥 収縮の影響と，温度変化による伸縮の影響によるものと 考えられる変位が見られ, 収縮側に変位が累積しつつ, 温度に応じて伸縮していることが確認された。

(2)層別沈下計の計測結果より，セメント改良アプローチ ブロックが逆台形型の形状であり，壁体より離れた位置 ほど現地盤の圧密沈下が生じていることから，アプロー チブロックが剛体的に背面側に回転変形し，相対水平変 位計の固定端に変位が生じているものと想定される.

(3)背面のアプローチブロックの側での変位が懸念される 際は，これによる補強材の引張変位の影響を設計作用と して考慮する必要があると考えられる．特にセメント改 良アプローチブロックが下側を短辺とする台形形状とな る場合は, この影響について注意が必要と考えられる.

なお，補強材の累積変位および絽返し変位による影 響については，実大載荷試験らにおいて検証されており， その結果から, 今回確認された補強材の累積変位は限界 変位に対して十分小さいことを別途確認している.

\section{参考文献}

1) 龍岡文夫, 舘山勝, 平川大貴, 渡辺健治, 清田隆 : GRS一体 橋梁の特徵と開発経緯，ジオシンセティックス論文集，Vol.24, pp.205-210,2009.

2) 栗山亮介, 小島謙一, 渡辺和之, 米澤豊司, 佐藤貴史, 青 木一二三 : 新幹線に用いる補強土一体橋梁の施工時挙動, 第47回地盤工学研究発表会論文集（CD-Rom）, pp.1319-1320, 2012.

3) 栗山亮介, 小島謙一，森野達也，渡辺和之，青木一二三， 山田康裕 : 新幹線構造物に用いた補強盛土一体橋梁の動態 計測，ジオシンセティックス論文集,Vol.27,pp.149-156,2012.

4) 小島謙一, 野中隆博, 陶山雄介,青木一二三, 渡辺和之 : 補 強盛土一体橋梁における季節の温度変化に伴う挙動, ジオ シンセティックス論文集,Vol.28,pp.369-374,2013.

5) 加藤久也, 森野達也, 陶山雄介, 青木一二三, 西岡英俊, 小 島謙一：GRS一体橋梁の長スパン化を想定した補強盛土壁 の正負交番水平載荷圾験（その2: 試験結果）,第48回地盤工 学研究発表会論文集 (CD-Rom) ,pp.1543-1544,2013.

\section{Behaviors of girder and backfill of GRS integral bridge focusing on tension force of geosynthetics}

\section{Tetsuya SASAKI,Hidetoshi NISHIOKA, Kenichi KOJIMA, Yusuke TAKANO, Yusuke SUYAMA and Hifumi AOKI}

GRS integral bridge is applied for the first time as a railway structure in Hokkaido Shinkansen, and long-term and under-construction measurement are being carried out.From the characteristics of the GRS integral bridge, tensile displacement to geotextile occurs repeatedly by forced displacement due to expansion and contraction of concrete action.In addition, the possibility of tensile displacement to geotextile in the displacement-to-back direction of the approach block is caused to act is concerned.In this paper, to organize the data obtained from the long-term dynamics measurement, for the displacement situation back embankment and stretching behavior of the bridge part that affects the tensile displacement of geotextile, and the behavior of the actual structure was discussed.

KEYWORDS: GRS Integral Bridge, Geotextile, Tensile Displacement 